\title{
Gellan-related polysaccharides and the genus Sphingomonas
}

\author{
ThOMas J. PolLOCK* \\ Shin-Etsu Bio, Inc., 6650 Lusk Blvd., Suite B106, San Diego, CA 92121, USA
}

(Received 20 January 1993; revised 24 March 1993; accepted 13 April 1993)

\begin{abstract}
The biochemical and physiological characteristics of several different existing bacterial isolates which secrete gellan-related polysaccharides were compared. Although they were originally classified into diverse genera, these bacteria are shown here to be closely related to each other and to members of the genus Sphingomonas.
\end{abstract}

\section{Introduction}

Several bacteria isolated during the past two decades are known to secrete acidic heteropolysaccharides that contain a common repeating backbone structure related to gellan (Moorhouse, 1987). The common repeating tetrasaccharide is $[\rightarrow 3) \mathrm{Glc}(\beta 1 \rightarrow 4) \mathrm{GlcA}(\beta 1 \rightarrow 4) \mathrm{Glc}-$ $(\beta 1 \rightarrow 4) L-R h a$ or L-Man $(\beta 1 \rightarrow]$, where Glc is glucose, GlcA is glucuronic acid, $\mathrm{Rha}$ is rhamnose, and Man is mannose. In gellan (also called PS-60) the fourth sugar is L-Rha, while in polysaccharide NW11 it is L-Man. In polysaccharides PS-88 and PS-198 the fourth sugar is either L-Man or L-Rha. In addition to the common backbone, the gellan-related polysaccharides contain different sidegroups consisting of L-glycerate, $O$-acetyl groups, monosaccharides or disaccharides (Jansson et al., 1983, 1985, 1986; Kuo et al., 1986; Chowdhury et al., $1987 a, b$; O'Neill et al., 1990). These related polysaccharides and their bacterial origins are listed as the first ten entries in Table 1.

The bacteria producing gellan and related polysaccharides were originally relegated to diverse genera, including Pseudomonas, Alcaligenes, Azotobacter and Xanthobacter. Recently, another bacterium was isolated and shown to secrete a gellan-related polysaccharide with a composition similar to gellan and with the capacity to form gels after deacetylation (Anson et al., 1987). This isolate was tentatively classified as Pseudomonas paucimobilis, within a group of bacteria described by Holmes et al. (1977). Yabuuchi et al. (1990) proposed a new name for this group, Sphingomonas paucimobilis gen. nov. and comb. nov., based on sequence similarities of rRNA and the common presence of a rare sphingoglycolipid (Yamamoto et al., 1978; Kawahara et al., 1991). Similarity between the general characteristics of

*Tel. 6194558500 ; fax 6195872716. the members of the gellan group of bacteria and of Sphingomonas was apparent. For example, all were yellow-pigmented, nonfermentative, Gram-negative rodshaped bacteria. A re-evaluation of the biochemical and phyisological properties of these bacteria showed that all the producers of gellan-related polysaccharides were closely related and probably members of the genus Sphingomonas. In this work the gellan-related polysaccharides are referred to as 'sphingans' after the genus.

\section{Methods}

Bacterial strains and culture media. The original names, polysaccharides produced, sources and references for the bacteria used in this work are listed in Table 1. Luria-Bertani medium (LB) contained $10 \mathrm{~g}$ Bacto tryptone, $5 \mathrm{~g}$ Bacto yeast extract and $10 \mathrm{~g} \mathrm{NaCl}$ per litre of water. All Bacto products were from Difco. YM medium contained $3 \mathrm{~g}$ Bacto yeast extract, $3 \mathrm{~g}$ Bacto malt extract, $5 \mathrm{~g}$ Bacto peptone and $10 \mathrm{~g}$ Bacto dextrose per litre of water. $\mathrm{M} 9$ medium contained $6 \mathrm{~g} \mathrm{Na}_{2} \mathrm{HPO}_{4}$, $3 \mathrm{~g} \mathrm{KH}_{2} \mathrm{PO}_{4}, 0.5 \mathrm{~g} \mathrm{NaCl}$ and $1 \mathrm{~g} \mathrm{NH}_{4} \mathrm{Cl}$ per litre of water, with $10 \mathrm{ml}$ $10 \mathrm{~mm}-\mathrm{CaCl}_{2}$ and $1 \mathrm{ml} 1 \mathrm{M}-\mathrm{MgSO}_{4} \cdot 7 \mathrm{H}_{2} \mathrm{O}$ added after sterilization by autoclaving. Oxidation-fermentation medium (OF) contained $10 \mathrm{~g}$ Bacto peptone, $5 \mathrm{~g} \mathrm{NaCl}$ and $18 \mathrm{mg}$ phenol red per litre of water and was adjusted to $\mathrm{pH} \mathrm{7.2}$. The water was deionized and 1.5\% Difco agar was added for solid medium. Other nutrient plates were Bacto nutrient broth, Bacto TSA (trypticase soy agar) blood agar base (used without blood), Bacto Kligler iron agar (KIA) and Bacto MacConkey agar base.

Physiological tests for strain identification. Utilization of carbon sources was detected by the MicroLog1 system (release 3.00 of Biolog, Inc.); this measures an increase in respiration of cells which in turn causes an irreversible reduction of tetrazolium dye. Bacteria were grown from single colonies on TSA plates for $48 \mathrm{~h}$ at $28^{\circ} \mathrm{C}$. Some of the strains studied formed strongly adherent aggregates on plates or rafts of thousands of cells in liquid culture. Cells were partially disaggregated by grinding with a mini-pestle in a $1.5 \mathrm{ml}$ conical microtube containing $0.85 \% \mathrm{NaCl}$. The remaining large aggregates were allowed to settle for a few minutes and then separated from the suspended cells. The cell concentration was adjusted to match the turbidity standards supplied by Biolog and then the dispersed cells and small aggregates ( $<100$ cells per aggregate by microscopy) were 
Table 1. Source of bacterial strains and exopolysaccharides

\begin{tabular}{|c|c|c|c|}
\hline $\begin{array}{c}\text { Strain } \\
\text { designation* }\end{array}$ & $\begin{array}{c}\text { Original } \\
\text { classification }\end{array}$ & $\begin{array}{l}\text { Polysaccharide } \\
\text { produced }\end{array}$ & Reference \\
\hline ATCC 31461 & Pseudomonas elodea & PS-60 & Kang \& Veeder $(1982 a)$ \\
\hline ATCC 31554 & Pseudomonas sp. & PS-88 & Kang \& Veeder (1985) \\
\hline ATCC $31554 \mathrm{~V}$ & Pseudomonas sp. & PS-88 & This work \\
\hline ATCC 31853 & Alcaligenes sp. & PS-198 & Peik et al. (1985) \\
\hline ATCC $31853 \mathrm{~V}$ & Alcaligenes sp. & PS-198 & This work \\
\hline ATCC 31555 & Alcaligenes sp. & PS-130 & Kang \& Veeder $(1982 b)$ \\
\hline ATCC 31961 & Alcaligenes sp. & PS-194 & Peik et al. (1983) \\
\hline ATCC 31961V & Alcaligenes sp. & PS-194 & This work \\
\hline ATCC 21423 & Azotobacter indicus & PS-7 & Kang \& McNeely (1976) \\
\hline ATCC 53272 & Xanthobacter sp. & NW11 & $\begin{array}{l}\text { Robison \& Stipanovic } \\
\text { (1989) }\end{array}$ \\
\hline ATCC $29837^{\mathrm{T}}$ & $\begin{array}{l}\text { Sphingomonas } \\
\text { paucimobilis }\end{array}$ & & Holmes et al. (1977) \\
\hline Escherichia coli DH5 $\alpha$ & & & Raleigh et al. (1989) \\
\hline $\begin{array}{l}\text { Xanthomonas campestris } \\
\text { X55 }\end{array}$ & & Xanthan & Cadmus et al. (1976) \\
\hline $\begin{array}{l}\text { Pseudomonas aeruginosa } \\
8853\end{array}$ & & & $\begin{array}{l}\text { Darzins \& Chakrabarty } \\
\text { (1984) }\end{array}$ \\
\hline $\begin{array}{l}\text { Xanthobacter autotrophicus } \\
\text { DSM432 }\end{array}$ & & & Tunail \& Schlegel (1974) \\
\hline
\end{tabular}

* Strains designated ATCC were from the American Type Culture Collection, Rockville, MD, USA; other strains were from the referenced laboratories. V indicates a variant described in the text. ATCC 29837 is the type strain.

transferred to the wells of the GN MicroPlates (Biolog). Each of 95 wells contains a different carbon source and one well lacks a carbon source and is a negative control. The colour for each test well was compared by eye to the control well after $4-6 \mathrm{~h}$ and $24 \mathrm{~h}$ at $30^{\circ} \mathrm{C}$, and recorded as either ' - ' for no difference, ' + ' for a blue-purple colour darker than the control, or ' $\backslash$ ' for a borderline reaction. The pattern was compared with a Gram-negative data base including 569 isolates distributed in 82 genera. The program identifies a closest species and calculates a 'similarity index' which quantifies the acceptability of the identification.

Cytochrome oxidase was detected with Kovac's reagent $(1 \%, \mathrm{w} / \mathrm{v}$, $N, N, N^{\prime}, N^{\prime}$-tetramethyl-p-phenylenediamine dihydrochloride from Sigma) on filter paper. A blue colour within $10 \mathrm{~s}$ indicated positive oxidase activity. A positive catalase reaction was observed as gas bubbles evolving from a bacterial colony immersed in an equal volume of $3 \%(v / v)$ hydrogen peroxide. Indole was detected with $1 \%(w / v) p-$ dimethylaminocinnamaldehyde (Sigma) dissolved in $10 \%(\mathrm{v} / \mathrm{v}) \mathrm{HCl}$. A positive indole result was a blue-green colour. Hydrolysis of aesculin was shown by a reddish-black halo around colonies on agar plates containing $\mathrm{LB}$ medium, $0.1 \%$ aesculin and $0.05 \% \mathrm{FeSO}_{4}$. In addition to these tests, strains were cultured on MacConkey agar plates and Kligler iron agar slants (Koneman et al., 1988). Resistance to antibiotics was tested in liquid cultures of M9 medium containing $1 \%(\mathrm{w} / \mathrm{v}) \mathrm{D}-$ mannose with the antibiotic concentration at $20 \mu \mathrm{g} \mathrm{ml}^{-1}$. ATCC strains $31461,31554,31853,31555,31961$ and 21423 were cultured overnight and then scored as resistant (full growth), partly resistant (slightly turbid) and sensitive (no growth) compared to controls without antibiotics. Each strain was tested for its ability to grow on various sugars as sole carbon source. The strains were cultured overnight in M9 medium with $0.3 \%$ glucose and then sets of growth tubes containing M9 medium with or without $1 \%(\mathrm{w} / \mathrm{v})$ sugar were inoculated with one drop of the overnight cultures for a $1 \%(\mathrm{v} / \mathrm{v})$ inoculum.

Fatty acids and pigments. Fatty acids were analysed by the Microcheck Company (Northfield, VT, USA). Bacteria were grown on trypticase soy broth agar, total cellular lipids were saponified, fatty acids were methylated, and the fatty acid methyl esters were separated by gas chromatography and detected by flame ionization.

For pigment analysis each strain was grown at $30^{\circ} \mathrm{C}$ for $3-5 \mathrm{~d}$ on YM plates. About $100 \mu \mathrm{l}$ of aggregated cells were scraped from the agar surface and placed in $1.5 \mathrm{ml}$ capped microcentrifuge tubes. Methanol $(0.5 \mathrm{ml})$ was added to extract methanol-soluble pigments at $50^{\circ} \mathrm{C}$ for $5 \mathrm{~min}$. After centrifugation at $10000 \mathrm{~g}$ at $25^{\circ} \mathrm{C}$ for $5 \mathrm{~min}$ the supernatant was scanned for absorbance with a Beckman DU640 spectrophotometer using a methanol blank.

\section{Results}

\section{Metabolic fingerprints}

Oxidation of individual carbon sources was detected indirectly by observing the reduction of tetrazolium dye using the MicroLog1 system. Table 2 lists representaive results for each available strain of bacteria known to secrete a sphingan polysaccharide and Sphingomonas paucimobilis ATCC 29837, the type strain. The following compounds gave positive results for each strain: dextrin, glycogen, L-arabinose, cellobiose, D-fructose, D-galactose, gentobiose, D-glucose, maltose, D-mannose and methyl pyruvate. These compounds gave negative results for each strain: $N$-acetyl-D-galactosamine, adonitol, Darabitol, erythritol, myo-inositol, D-mannitol, D-sorbitol, formic acid, $\gamma$-hydroxybutyric acid, $p$-hydroxyphenylacetic acid, itaconic acid, malonic acid, sebacic acid, L-histidine, L-ornithine, L-phenylalanine, L-pyroglutamic acid, D-serine, DL-carnitine, $\gamma$-aminobutyric 
Table 2. Oxidation of carbon sources

For strain ATCC 21423 a $4 \mathrm{~h}$ assay was used; for the other strains the assay time was $24 \mathrm{~h}$. + , Positive reaction; $\backslash$, borderline; - , negative.

\begin{tabular}{|c|c|c|c|c|c|c|c|c|c|}
\hline \multicolumn{8}{|c|}{ ATCC strain no. } & \multirow{2}{*}{\multicolumn{2}{|c|}{$\begin{array}{l}\text { Well no. and } \\
\text { carbon source }\end{array}$}} \\
\hline 31461 & 31554 & 31853 & 31555 & 31961 & 21423 & 53272 & 29837 & & \\
\hline - & - & - & - & - & - & - & - & Al & None \\
\hline+ & + & + & - & + & + & - & + & A2 & $\alpha$-Cyclodextrin \\
\hline 1 & + & - & + & 1 & - & 1 & + & A5 & Tween 40 \\
\hline+ & + & - & + & 1 & - & 1 & + & A6 & Tween 80 \\
\hline+ & + & + & + & + & - & - & + & A8 & $N$-Acetyl-D-glucosamine \\
\hline 1 & - & 1 & - & - & - & - & - & B3 & L-Fucose \\
\hline+ & + & + & + & + & 1 & - & + & B8 & D-Lactose \\
\hline+ & + & + & + & + & 1 & - & + & B9 & Lactulose \\
\hline+ & + & 1 & + & + & + & + & + & $\mathrm{C} 1$ & D-Melibiose \\
\hline+ & + & + & + & 1 & + & - & + & $\mathrm{C} 2$ & Methyl $\beta$-D-glucoside \\
\hline 1 & + & + & 1 & 1 & + & - & + & $\mathrm{C} 3$ & D-Psicose \\
\hline+ & + & $\backslash$ & - & + & + & - & + & $\mathrm{C} 4$ & D-Raffinose \\
\hline+ & + & - & - & 1 & - & + & - & $\mathrm{C} 5$ & L-Rhamnose \\
\hline+ & + & + & 1 & + & + & - & + & C7 & Sucrose \\
\hline 1 & + & + & 1 & 1 & + & - & + & $\mathrm{C} 8$ & D-Trehalose \\
\hline 1 & + & + & 1 & 1 & + & - & + & C9 & Turanose \\
\hline- & - & - & 1 & - & - & - & - & $\mathrm{C} 10$ & Xylitol \\
\hline- & 1 & + & 1 & - & - & + & + & $\mathrm{C} 12$ & Monomethyl succinate \\
\hline- & + & - & + & - & + & $\backslash$ & + & D1 & Acetic acid \\
\hline- & - & - & 1 & - & - & - & + & D2 & cis-Aconitic acid \\
\hline- & - & - & 1 & - & - & - & - & D3 & Citric acid \\
\hline- & - & 1 & 1 & - & - & - & - & D5 & D-Galactonic acid lactone \\
\hline- & - & 1 & + & 1 & - & - & - & D6 & D-Galacturonic acid \\
\hline - & - & - & 1 & - & - & - & - & D7 & D-Gluconic acid \\
\hline - & - & - & 1 & - & - & - & - & D8 & D-Glucosaminic acid \\
\hline+ & + & + & + & + & - & - & - & D9 & D-Glucuronic acid \\
\hline- & - & - & 1 & - & - & + & + & D10 & $\alpha$-Hydroxybutyric acid \\
\hline+ & + & + & + & + & - & + & + & D11 & $\beta$-Hydroxybutyric acid \\
\hline+ & + & + & + & 1 & - & + & + & E3 & $\alpha$-Ketobutyric acid \\
\hline 1 & - & + & 1 & - & - & - & - & E4 & $\alpha$-Ketoglutaric acid \\
\hline 1 & - & - & + & - & - & + & + & E5 & $\alpha$-Ketovaleric acid \\
\hline- & - & $\backslash$ & $\backslash$ & $\backslash$ & - & + & - & E6 & DL-Lactic acid \\
\hline- & 1 & - & + & - & - & + & - & E8 & Propionic acid \\
\hline- & - & 1 & - & - & - & - & - & E9 & Quinic acid \\
\hline- & - & 1 & - & - & - & - & - & E10 & D-Saccharic acid \\
\hline+ & + & + & + & 1 & - & - & + & E12 & Succinic acid \\
\hline+ & + & + & + & 1 & - & - & + & $\mathrm{F} 1$ & Bromosuccinic acid \\
\hline- & - & - & - & 1 & - & - & - & F2 & Succinamic acid \\
\hline- & - & - & - & 1 & - & - & - & F3 & Glucuronamide \\
\hline+ & + & + & + & + & + & - & + & F4 & Alaninamide \\
\hline- & 1 & - & - & 1 & - & - & - & F5 & D-Alanine \\
\hline+ & + & + & + & + & + & - & + & F6 & L-Alanine \\
\hline+ & + & + & + & + & + & - & + & F7 & L-Alanylglycine \\
\hline- & - & - & - & 1 & - & + & + & F8 & L-Asparagine \\
\hline- & - & - & + & 1 & - & - & + & F9 & L-Aspartic acid \\
\hline+ & $\backslash$ & 1 & + & + & + & $\backslash$ & + & F10 & L-Glutamic acid \\
\hline- & - & 1 & - & 1 & - & + & - & F11 & Glycyl-L-aspartic acid \\
\hline 1 & $\backslash$ & + & + & 1 & + & + & + & F12 & Glycyl-L-glutamic acid \\
\hline$\backslash$ & - & + & 1 & + & $\backslash$ & - & + & G2 & Hydroxy-L-proline \\
\hline 1 & - & - & 1 & + & - & - & + & G3 & L-Leucine \\
\hline 1 & 1 & 1 & 1 & + & 1 & - & + & G6 & L-Proline \\
\hline 1 & 1 & - & - & + & + & - & + & G9 & L-Serine \\
\hline 1 & - & - & - & - & - & - & + & G10 & L-Threonine \\
\hline- & - & - & $\backslash$ & - & - & - & - & $\mathrm{H} 9$ & Glycerol \\
\hline- & - & 1 & - & - & - & - & - & H11 & Glucose 1-phosphate \\
\hline- & - & 1 & - & - & - & - & - & H12 & Glucose 6-phosphate \\
\hline
\end{tabular}

acid, urocanic acid, inosine, uridine, thymidine, phenylethylamine, putrescine, 2-aminoethanol, 2,3-butanediol and DL- $\alpha$-glycerol phosphate. All the strains except
ATCC 53272 were identified by the MicroLog1 program as the species Pseudomonas (Sphingomonas) paucimobilis A, with similarity indices ranging from 0.75 to 0.91 , 
Table 3. Fatty acids of S. paucimobilis and sphingan-producing bacteria

\begin{tabular}{|c|c|c|c|c|c|c|c|c|c|c|c|}
\hline \multirow[b]{2}{*}{ Strain } & \multicolumn{11}{|c|}{ Percentage in profile* } \\
\hline & $14: 0$ & $\begin{array}{c}14: 0 \\
2-\mathrm{OH}\end{array}$ & $15: 0$ & $16: 0$ & $\begin{array}{l}16: 1 \\
\text { cis-9 }\end{array}$ & $\begin{array}{c}16: 1 \\
\mathrm{C}\end{array}$ & $17: 0$ & $\begin{array}{c}17: 1 \\
\mathrm{C}\end{array}$ & $18: 0$ & $\begin{array}{c}18: 1 \\
\text { B }\end{array}$ & $\begin{array}{c}18: 1 \\
c i s-11\end{array}$ \\
\hline Yabuuchi† & $\begin{array}{l}1 \cdot 1 \\
(0 \cdot 4)\end{array}$ & $\begin{array}{c}24 \cdot 3 \\
(5 \cdot 2)\end{array}$ & $\begin{array}{l}0 \\
-\end{array}$ & $\begin{array}{l}10 \cdot 7 \\
(1 \cdot 1)\end{array}$ & $\begin{array}{c}3 \cdot 0 \\
(1 \cdot 5)\end{array}$ & - & $\begin{array}{l}0 \\
-\end{array}$ & $\begin{array}{c}1 \cdot 0 \\
(0 \cdot 1)\end{array}$ & $\begin{array}{l}0 \\
-\end{array}$ & $\begin{array}{l}0 \\
-\end{array}$ & $\begin{array}{l}58 \cdot 0 \\
(3 \cdot 6)\end{array}$ \\
\hline Stead $\ddagger$ & $\begin{array}{c}0.6 \\
(0 \cdot 2)\end{array}$ & $\begin{array}{c}7 \cdot 7 \\
(1 \cdot 3)\end{array}$ & $\begin{array}{l}0 \\
-\end{array}$ & $\begin{array}{c}14 \cdot 0 \\
(1 \cdot 8)\end{array}$ & $\begin{array}{c}8 \cdot 2 \\
(1 \cdot 3)\end{array}$ & $\begin{array}{c}1 \cdot 0 \\
(0 \cdot 1)\end{array}$ & $\begin{array}{l}0 \\
-\end{array}$ & $\begin{array}{c}1 \cdot 0 \\
(0 \cdot 7)\end{array}$ & $\begin{array}{c}0.8 \\
(0 \cdot 2)\end{array}$ & $\begin{array}{c}1 \cdot 1 \\
(0 \cdot 2)\end{array}$ & $\begin{array}{c}65 \cdot 2 \\
(1 \cdot 0)\end{array}$ \\
\hline Microcheck§ & 1 & 5 & 0 & 9 & 4 & 1 & - & 2 & - & 2 & 76 \\
\hline $\begin{array}{l}\text { ATCC } 31554 \\
\text { ATCC } 31554 \mathrm{~V}\end{array}$ & $\begin{array}{l}0 \\
0\end{array}$ & $\begin{array}{l}7 \\
8\end{array}$ & $\begin{array}{l}1 \\
0\end{array}$ & $\begin{array}{l}18 \\
24\end{array}$ & $\begin{array}{l}4 \\
2\end{array}$ & $\begin{array}{l}2 \\
0\end{array}$ & $\begin{array}{l}0 \\
0\end{array}$ & $\begin{array}{l}6 \\
3\end{array}$ & $\begin{array}{l}0 \\
0\end{array}$ & $\begin{array}{l}0 \\
0\end{array}$ & $\begin{array}{l}62 \\
63\end{array}$ \\
\hline $\begin{array}{l}\text { ATCC } 31853 \\
\text { ATCC } 31853 \mathrm{~V}\end{array}$ & $\begin{array}{l}1 \\
0\end{array}$ & $\begin{array}{l}14 \\
12\end{array}$ & $\begin{array}{l}0 \\
0\end{array}$ & $\begin{array}{l}22 \\
24\end{array}$ & $\begin{array}{l}0 \\
0\end{array}$ & $\begin{array}{l}0 \\
0\end{array}$ & $\begin{array}{l}0 \\
0\end{array}$ & $\begin{array}{l}0 \\
0\end{array}$ & $\begin{array}{l}0 \\
0\end{array}$ & $\begin{array}{l}0 \\
0\end{array}$ & $\begin{array}{l}61 \\
64\end{array}$ \\
\hline $\begin{array}{l}\text { ATCC } 31961 \\
\text { ATCC } 31961 \mathrm{~V}\end{array}$ & $\begin{array}{l}0 \\
0\end{array}$ & $\begin{array}{l}13 \\
13\end{array}$ & $\begin{array}{l}0 \\
0\end{array}$ & $\begin{array}{l}16 \\
15\end{array}$ & $\begin{array}{l}3 \\
3\end{array}$ & $\begin{array}{l}1 \\
1\end{array}$ & $\begin{array}{l}0 \\
0\end{array}$ & $\begin{array}{l}0 \\
1\end{array}$ & $\begin{array}{l}0 \\
0\end{array}$ & $\begin{array}{l}0 \\
0\end{array}$ & $\begin{array}{l}66 \\
66\end{array}$ \\
\hline ATCC 21423 & 0 & 16 & 0 & 12 & 3 & 0 & 0 & 3 & 0 & 0 & 66 \\
\hline
\end{tabular}

* Shorthand names of fatty acids: 14:0, tetradecanoic (myristic) acid; 14:0 2-OH, 2hydroxytetradecanoic acid; 15:0, pentadecanoic acid; 16:0, hexadecanoic (palmitic) acid; 16:1 cis-9, cis-9-hexadecenoic (palmitoleic) acid; 16:1 C, hexadecenoic acid isomer C; 17:0, heptadecanoic (margaric) acid; 17:1 C, heptadecenoic acid isomer $\mathrm{C}$; 18:0, octadecanoic (stearic) acid; 18:1 B, octadecenoic acid isomer B; and 18:1 cis-11, cis-11-octadecenoic (cis-vaccenic) acid.

$\dagger$ Means and (standard deviations) for seven different strains of S. paucimobilis (Yabuuchi et al., 1990). Dashes indicate no measurement.

¥Means and (standard deviations) for four different strains of S. paucimobilis (Stead, 1992).

§Type strain ATCC $29837^{\mathrm{T}}$.

where $>0.75$ indicates a close fit. Strain ATCC 53272 was identified as $P$. paucimobilis $\mathrm{B}$ with a similarity index of 0.60 . The subgroups $A$ and $B$ are unofficial designations of Biolog used to indicate that some of their strains of $P$. paucimobilis do not match closely the characteristics of the type strain ATCC 29837, which is in subgroup A.

\section{Fatty acids}

As received from ATCC, there were some slight differences in the translucence of colonies among the progeny derived from three strains: ATCC 31554, 31853 and 31961. In order to distinguish between variation of a strain and contamination, these were sent to the Microcheck Corporation for strain identification based on fatty acid analysis. In Table 3 the percentage compositions of fatty acids extracted from these strains are compared with similarly treated standards of $S$. paucimobilis. Each strain was tested once. All the strains showed the major fatty acid as cis-11-octadecenoic acid (18:1 cis-11; cis-vaccenic acid). The second most prevalent fatty acid was hexadecanoic acid (palmitic acid; 16:0). The presence of 2-hydroxymyristic acid (2-OH $14: 0$ ) as the only hydroxylated fatty acid is typical of all Sphingomonas members. However, the presence of sphingolipid was not investigated in this study. The similarity of the fatty acid profiles for the pairs of strains
(ATCC 31554 and $31554 \mathrm{~V} ; 31853$ and $31853 \mathrm{~V} ; 31961$ and $31961 \mathrm{~V}$ ) suggested that they were closely related variants. According to the similarity analysis by Microcheck, ATCC strains 31554, 31853, 31961 and 21423 were related to each other at the genus level, and nearly to the species level with $S$. paucimobilis.

\section{Absorbance spectra of pigments}

Methanol-soluble pigments extracted from whole cells of each of the sphingan-polysaccharide-secreting isolates showed absorbance spectra as described previously for $P$. paucimobilis, but distinct from Xanthomonas campestris (Holmes et al., 1977; Jenkins et al., 1979), which is also yellow in pigmentation. A representative spectrum for each included a major peak centred at 449 to $451 \mathrm{~nm}$, a secondary peak at 475 to $478 \mathrm{~nm}$, and a slight inflection between about 415 and $430 \mathrm{~nm}$. By contrast the methanol-soluble pigments from $X$. campestris showed a major peak at $446 \mathrm{~nm}$, and two slight inflections at about 465 to $480 \mathrm{~nm}$ and 420 to $425 \mathrm{~nm}$.

\section{Other characteristics}

The seven members of the sphingan group and four control bacterial strains were analysed for other biochemical properties. As shown by the representative 
Table 4. Characteristics of the gellan group of strains and bacterial standards

\begin{tabular}{|c|c|c|c|c|c|c|c|c|c|c|c|}
\hline \multirow[b]{2}{*}{ Characteristic } & \multicolumn{11}{|c|}{ Strain* } \\
\hline & 1 & 2 & 3 & 4 & 5 & 6 & 7 & $\mathrm{Xc}$ & $\mathrm{Ec}$ & $\mathrm{Pa}$ & $\mathrm{Xa}$ \\
\hline Aesculin hydrolysis & + & + & + & + & + & + & + & + & - & - & - \\
\hline Growth on MacConkey & - & - & - & - & - & - & - & - & + & - & - \\
\hline Indole production & - & - & - & - & - & - & - & - & + & - & - \\
\hline Oxidase (Kovac's) & - & - & - & - & - & - & - & - & - & + & + \\
\hline Catalase & + & + & + & + & + & + & + & + & + & + & + \\
\hline \multicolumn{12}{|l|}{ KIA (slant/butt) } \\
\hline $\begin{array}{l}\text { Growth } \\
\mathrm{pH} \dagger\end{array}$ & $\begin{array}{l}+/- \\
\mathbf{K} / \mathbf{K}\end{array}$ & $\begin{array}{l}+/- \\
\mathrm{K} / \mathrm{K}\end{array}$ & $\begin{array}{l}+/- \\
\mathrm{K} / \mathrm{K}\end{array}$ & $\begin{array}{l}+/- \\
\mathrm{K} / \mathrm{K}\end{array}$ & $\begin{array}{l}+/- \\
\mathrm{K} / \mathrm{K}\end{array}$ & $\begin{array}{l}+/- \\
\mathrm{K} / \mathrm{K}\end{array}$ & $\begin{array}{l}+/- \\
\mathrm{K} / \mathrm{K}\end{array}$ & $\begin{array}{l}+/- \\
\mathbf{K} / \mathbf{K}\end{array}$ & $\begin{array}{l}+/+ \\
\mathrm{K} / \mathrm{A}\end{array}$ & $\begin{array}{l}+/- \\
\mathrm{K} / \mathrm{K}\end{array}$ & $\begin{array}{l}+/+ \\
\mathrm{K} / \mathrm{A}\end{array}$ \\
\hline \multicolumn{12}{|l|}{ Sugar sourcef: } \\
\hline L-Arabinose & yo & yo & yo & or & yo & yo & $\mathrm{y}$ & or & $\mathrm{y}$ & $\mathbf{r}$ & NT \\
\hline Fructose & or & o & $\mathrm{y}$ & $\mathbf{y}$ & $\mathbf{r}$ & yo & $\mathbf{r}$ & or & $\mathbf{y}$ & $\mathbf{r}$ & NT \\
\hline Galactose & $\mathbf{y}$ & yo & yo & or & $\mathrm{y}$ & $\mathrm{y}$ & 0 & or & $\mathrm{y}$ & $\mathbf{r}$ & NT \\
\hline Glucose & yo & yo & $y$ & $\mathrm{y}$ & yo & yo & or & or & $y$ & $\mathbf{r}$ & NT \\
\hline Lactose & yo & yo & or & or & yo & $\mathrm{r}$ & $\mathrm{r}$ & $\mathrm{r}$ & $\mathrm{y}$ & $\mathbf{r}$ & NT \\
\hline Maltose & yo & yo & yo & $\mathrm{y}$ & 0 & yo & or & or & $\mathrm{y}$ & $\mathbf{r}$ & NT \\
\hline Mannose & yo & yo & yo & $\mathrm{y}$ & yo & yo & $\mathrm{r}$ & or & $\mathrm{y}$ & $\mathrm{r}$ & NT \\
\hline Raffinose & 0 & 0 & or & $\mathrm{r}$ & or & or & $\mathbf{r}$ & $\mathrm{r}$ & $r$ & $\mathbf{r}$ & NT \\
\hline L-Rhamnose & 0 & yo & $\mathrm{r}$ & o & $r$ & $\mathrm{r}$ & or & $\mathrm{r}$ & yo & $\mathbf{r}$ & NT \\
\hline Salicin & 0 & yo & $\mathrm{y}$ & $\mathrm{y}$ & o & or & $\mathrm{r}$ & $\mathrm{r}$ & $\mathrm{r}$ & $\mathrm{r}$ & NT \\
\hline Sucrose & yo & 0 & $\mathrm{y}$ & yo & o & yo & $\mathbf{r}$ & or & $\mathrm{r}$ & $\mathbf{r}$ & NT \\
\hline None & $r$ & or & $\mathrm{r}$ & $r$ & or & $\mathrm{r}$ & $\mathrm{r}$ & $\mathrm{r}$ & $\mathbf{r}$ & $\mathrm{r}$ & NT \\
\hline
\end{tabular}

* Strain abbreviations: 1 , ATCC $31461 ; 2$, ATCC $31554 ; 3$, ATCC $31853 ; 4$, ATCC $31555 ; 5$, ATCC $31961 ; 6$, ATCC 21423; 7, ATCC 53272; Xc, Xanthomonas campestris X55; Ec, E. coli DH5 $\alpha ; \mathrm{Pa}, P$. aeruginosa $8853 ; \mathrm{Xa}$, Xanthobacter autotrophicus DSM432.

$\dagger \mathrm{K}$, alkaline; A, acidic.

$\ddagger$ Strains were cultured in OF medium with the indicated sugar (D-form unless noted) at $1 \%\left(\mathrm{w} / \mathrm{v}\right.$ ) for $24 \mathrm{~h}$ at $32^{\circ} \mathrm{C}$. Symbols (colour) and $\mathrm{pH}: \mathrm{y}$ (yellow) <6.5; yo (yellow-orange) 6.8; o (orange) 7.1; or (orange-red) 7.4; r (red) $>7.7$; NT, not tested.

results in Table 4, all members of the sphingan group hydrolysed aesculin, failed to grow on MacConkey agar, were negative for tryptophanase (indole production) and cytochrome oxidase, and were positive for catalase. Each grew only on the slant on Kligler iron agar tubes and were alkaline throughout. The results in Table 4 also show the $\mathrm{pH}$-indicating colours of cultures grown with various sugar sources. The pattern can be used to distinguish these closely related isolates.

All of the sphingan-producing strains were resistant to $20 \mu \mathrm{g} \mathrm{ml}^{-1}$ of ampicillin, streptomycin, kasugamycin or hygromycin $\mathrm{B}$, and partly resistant to kanamycin. They were sensitive to rifampicin and vancomycin at $20 \mu \mathrm{g} \mathrm{ml}^{-1}$. ATCC strains 31461, 31554, 31853 and 31961 were partly resistant to both tetracycline and chloramphenicol, while 31555 and 21423 were sensitive to both drugs. Additionally, all the strains were resistant to streptomycin in agar plates at $60 \mu \mathrm{g} \mathrm{ml}^{-1}$. Lastly, all the strains grew in liquid minimal medium (M9) in the absence of $\mathrm{NaCl}$, and including $0.2 \% \mathrm{D}$-mannose, and ampicillin, streptomycin, kasugamycin and hygromycin B each at $20 \mu \mathrm{g} \mathrm{ml}^{-1}$. However ATCC 31961 grew less densely.

ATCC strains 31853 and 31555 could grow on any of the following sugars as the sole carbon source: Larabinose, D-fructose, D-galactose, D-glucose, D-lactose,
D-maltose, D-mannose, D-raffinose, L-rhamnose, salicin, and D-sucrose. However, from this list of sugars ATCC strain 31461 failed to use D-raffinose; 31554 failed to use D-raffinose, L-rhamnose and D-sucrose; 31961 failed to use D-raffinose and L-rhamnose; 21423 failed to use Lrhamnose; and 53272 failed to use D-lactose, D-mannose and salicin, and used D-fructose and D-raffinose only marginally. Only for L-arabinose were the cultures uniformly dense. The patterns of sugar utilization, substrate metabolism and respiration can be used to distinguish between the members of the gellan group.

\section{Discussion}

Several bacterial isolates that synthesize structurally related exopolysaccharides were originally classified into diverse genera. A re-examination of the biochemical and physiological characteristics of those bacteria indicates that they are actually closely related to each other and to Sphingomonas paucimobilis, previously referred to as Pseudomonas paucimobilis. They share with $S$. paucimobilis a specific pattern of oxidization of carbon compounds. In addition their fatty acid profiles and absorption spectra for methanol-soluble pigments are indistinguishable from Sphingomonas, and they share several other characteristics. From a biotechnological 
standpoint the most important common characteristic is the secretion of sphingan polysaccharides, including gellan, welan and rhamsan. These and other members of the group are the result of a successful screening effort by the Kelco Company for polysaccharides produced by bacteria that might have food and industrial applications (Moorhouse, 1987). At this time we do not know if these isolates belong to one or more of the previously identified species of Sphingomonas (Yabuuchi et al., 1990). An additional bacterial isolate that also secretes a sphingan polysaccharide was recently assigned to the genus Xanthomonas (Peik et al., 1987). However because it also secretes a sphingan polysaccharide, it may be necessary to look more closely at this assignment when the strain is available for study.

The relatedness between the sphingan-producers and Sphingomonas species may have implications for human health. The sphingan-secreting bacteria were isolated from soil and water samples from diverse environmental locations. A few other strains of $P$. paucimobilis were isolated from soil: two with the ability to degrade the biphenyl structures in lignin compounds (Katayama et $a l ., 1988$ ) and polychlorinated biphenyls (Taira et al., 1988); one that degrades the herbicide phosphinothricin (Tebbe \& Reber, 1988); and one that may be a root pathogen of lettuce (van Bruggen et al., 1989). However, most of the strains of $S$. paucimobilis were isolated from human clinical specimens and samples of water taken from hospital environments (Holmes et al., 1977; Yabuuchi et al., 1990) and a possible pathogenic role for Sphingomonas in humans is emerging (Reina et al., 1991; Decker et al., 1992; Casadevall et al., 1992), but not yet well established. By analogy with alginic acid, the polysaccharide secreted by pathogenic Pseudomonas aeruginosa, it is conceivable that acidic sphingan heteropolysaccharides might play a similar role in pathogenesis for $S$. paucimobilis. Also, it may be necessary to modify some industrial methods for producing the useful polysaccharides by fermentation and handling of the dry polysaccharide powders to reduce exposure of operators to airborne contaminants.

Based on this work the capacity for polysaccharide production appears to be a more common characteristic of $S$. paucimobilis than was previously recognized. Recently, two new isolates of $P$. paucimobilis were shown to produce polysaccharides that seem to be related to gellan in sugar composition (Balandreau et al., 1990; Then et al., 1989). A different earlier isolate of Sphingomonas capsulata was initially reported to have a capsule but the trait disappeared from the only remaining progeny (Yabuuchi et al., 1990). Exopolysaccharide production is usually most obvious when bacteria are supplied with abundant sugar and with minimal nitrogen. Thus it is possible that other Sphingomonas species whose colonies are not obviously mucoid in appearance might also have the capacity to secrete polysaccharides when supplied with the right conditions. Since the existing members of the sphingan group secrete polysaccharides with special and potentially useful commercial properties, it is reasonable to expect that new isolates of Sphingomonas might also make commercially useful products with different rheological properties based on slightly different structures.

I acknowledge R. W. Armentrout, M. Mikolajczak, I. Ratliff, L. Thorne and M. Yamazaki for daily encouragement, Shin-Etsu Chemical Company for facilities and support, and Michael Sinclair of Microcheck and Barry Bochner of Biolog for assistance with strain identifications.

\section{References}

Anson, A., Fisher, P. J., Kennedy, A. F. D. \& Sutherland, I. W. (1987). A bacterium yielding a polysaccharide with unusual properties. Journal of Applied Bacteriology 62, 147-150.

Balandreau, J., Gueniot, B. \& Hebbar, P. (1990). Polysaccharides, procédé pour leur preparation par culture Pseudomonas paucimobilis et application des souches en agriculture. European Patent 0353145A1.

Cadmus, M. C., Rogovin, S. P., Burton, K. A. \& Pittsley, J. E. (1976). Colonial variation in Xanthomonas campestris NRRL B-1459 and characterization of the polysaccharide from a variant strain. Canadian Journal of Microbiology 22, 942-948.

van Bruggen, A. H. C., Brown, P. R. \& Jochimsen, K. N. (1989). Corky root of lettuce caused by strains of a gram-negative bacterium from muck soils of Florida, New York and Wisconsin USA. Applied and Environmental Microbiology 55, 2635-2640.

Casadevall, A., Freundlich, L. F. \& Pirofski, L. (1992). Septic shock caused by Pseudomonas paucimobilis. Clinical Infectious Diseases 14, 784.

CHOWDHuRY, T. A., LINDBerg, B., LINDQuIST, U. \& BAIRD, J. (1987 a). Structural studies of an extracellular polysaccharide (S-198) elaborated by Alcaligenes ATCC 31853. Carbohydrate Research 161, 127-132.

Chowdhury, T. A., LINDBerg, B., LindQuist, U. \& BAIRD, J. (1987b). Structural studies of an extracellular polysaccharide, S-657, elaborated by Xanthomonas ATCC 53159. Carbohydrate Research 164, 117-122.

Darzins, A. \& Chakrabarty, A. M. (1984). Cloning of genes controlling alginate biosynthesis from a mucoid cystic fibrosis isolate of Pseudomonas aeruginosa. Journal of Bacteriology 159, 9-18.

DeCker, C. F., Hawkins, R. E. \& Simon, G. L. (1992). Infections with Pseudomonas paucimobilis. Clinical Infectious Diseases 14, 783-784.

Holmes, B., Owen, R. J., Evans, A., Malnick, H. \& Willcox, W. R. (1977). Pseudomonas paucimobilis, a new species isolated from human clinical specimens, the hospital environment, and other sources. International Journal of Systematic Bacteriology 27, 133-146.

JANSSON, P.-E., LINDBERG, B. \& SANDFORD, P. A. (1983). Structural studies of gellan gum, an extracellular polysaccharide elaborated by Pseudomonas elodea. Carbohydrate Research 124, 135-139.

Jansson, P.-E., LINDBerg, B., Widmalm, G. \& SANDFord, P. A. (1985). Structural studies of an extracellular polysaccharide (S-130) elaborated by Alcaligenes ATCC 31555. Carbohydrate Research 139, 217-223.

Jansson, P.-E., Kumar, N. S. \& Lindberg, B. (1986). Structural studies of a polysaccharide (S-88) elaborated by Pseudomonas ATCC 31554. Carbohydrate Research 156, 165-172.

Jenkins, C. L., Andrewes, A. G., McQuade, T. J. \& Stark, M. P. (1979). The pigment of Pseudomonas paucimobilis is a carotenoid (nostoxanthin), rather than a brominated arylpolyene (xanthomonadin). Current Microbiology 3, 1-4. 
KanG, K. S. \& MCNeELY, W. H. (1976). Polysaccharide and bacterial fermentation process for its preparation. United States Patent 3960832.

KANG, K. S. \& VeEDER, G. T. (1982a). Gellan polysaccharide S-60 and bacterial fermentation process for its preparation. United States Patent 4326053.

KANG, K. S. \& VeEder, G. T. (1982b). Heteropolysaccharide S-130. United States Patent 4342866.

KANG, K. S. \& VeEDER, G. T. (1985). Heteropolysaccharide S-88. United States Patent 4535153.

Katayama, Y., Nishikawa, S., Murayama, A., Yamasaki, M., Morohoshi, N. \& Haraguchi, T. (1988). The metabolism of biphenyl structures in lignin by the soil bacterium (Pseudomonas paucimobilis SYK-6). FEBS Letters 233, 129-133.

Kawahara, K., Seydel, U., MatsuUra, M., Danbara, H., Rietschel, E. T. \& ZÄHRINGER, U. (1991). Chemical structure of glycosphingolipids isolated from Sphingomonas paucimobilis. FEBS Letters 292, 107-110.

Koneman, E. W., Allen, S. D., Dowell, V. R., JR, Janda, W. M., SOMmers, H. M. \& WINN, W. C., JR (1988). Color Atlas and Textbook of Diagnostic Microbiology, p. 95. Philadelphia: J. B. Lippincott Company.

KUo, M.-S., MORT, A. J. \& DelL, A. (1986). Identification and location of L-glycerate, an unusual acyl substituent in gellan gum. Carbohydrate Research 156, 173-187.

MOORHOUSE, R. (1987). Structure/property relationships of a family of microbial polysaccharides. In Industrial Polysaccharides: Genetic Engineering, Structure/Property Relations and Applications, p. 187-206. Edited by M. Yalpani. Amsterdam: Elsevier.

O'Neill, M. A., Darvill, A. G., Albersheim, P. \& Chou, K. J. (1990). Structural analysis of an acidic polysaccharide secreted by Xanthobacter sp. (ATCC 53272). Carbohydrate Research 206, 289-296.

Peik, J. A., Steenbergen, S. M. \& Hayden, H. R. (1983). Heteropolysaccharide S-194. United States Patent 4401760.

Peik, J. A., Steenbergen, S. M. \& Hayden, H. R. (1985). Heteropolysaccharide S-198. United States Patent 4529797.

Peik, J. A., Steenbergen, S. M. \& Veeder, G. T. (1987). Hetero- polysaccharide and its production and use. European Patent Application 209277A1.

Raleigh, E. A., LeCh, K. \& Brent, R. (1989). Selected topics from classical bacterial genetics. In Current Protocols in Molecular Biology, Unit 1.4. Edited by F. M. Ausubel, R. Brent, R. E. Kingston, D. D. Moore, J. G. Seidman, J. A. Smith \& K. Struhl. Boston: Wiley Interscience.

Reina, J., Bassa, A., Llompart, I., Portela, D. \& Borrell, N. (1991). Infections with Pseudomonas paucimobilis: report of four cases and review. Reviews of Infectious Diseases 13, 1072-1076.

Robison, P. D. \& Stipanovic, A. J. (1989). Method for oil recovery using a modified heteropolysaccharide. United States Patent 4874044

STEAD, D. E. (1992). Grouping of plant-pathogenic and some other Pseudomonas spp. by using cellular fatty acid profiles. International Journal of Systematic Bacteriology 42, 281-295.

Taira, K., Hayase, N., Arimura, N., Yamashita, S., Miyazaki, T. \& Furukawa, K. (1988). Cloning and nucleotide sequence of the 2,3dihydroxybiphenyl dioxygenase gene from the PCB-degrading strain of Pseudomonas paucimobilis Q1. Biochemistry 27, 3990-3996.

TebBe, C. C. \& ReBER, H. H. (1988). Utilization of the herbicide phosphinothricin as a nitrogen source by soil bacteria. Applied Microbiology Biotechnology 29, 103-105.

Then, J., Giani, C., Wöhner, G., Wink, J., BuchHolz, R., Voelskow, H., Schlingmann, M., Rapp, K. \& Vogel, M. (1989). Neues rhamnosehaltiges Polysaccharid, Verfahren zu seiner Herstellung und seine Verwendung. European Patent 0339445A1.

TunaIL, N. \& SCHLEGEL, H. G. (1974). A new coryneform hydrogen bacterium: Corynbacterium autotrophicum strain 7C. I. Characterization of the wild type strain. Archives of Microbiology 10, 341-350.

YabuUchi, E., Yano, I., Oyaizu, H., Hashimoto, Y., Ezaki, T. \& Yamamoto, H. (1990). Proposals of Sphingomonas paucimobilis gen. nov. and comb. nov., Sphingomonas parapaucimobilis sp. nov., Sphingomonas yanoikuyae sp. nov., Sphingomonas adhaesiva sp. nov., Sphingomonas capsulata comb. nov., and two genospecies of the genus Sphingomonas. Microbiology and Immunology 34, 99-119.

Yamamoto, A., Yano, I., Masu, M. \& YabUUChi, E. (1978). Isolation of a novel sphingoglycolipid containing glucuronic acid and 2hydroxy fatty acid from Flavobacterium devorans ATCC 10829. Journal of Biochemistry 83, 1213-1216. 